DOI https://doi.org/10.30525/978-9934-26-039-1-8

\title{
СУЧАСНІ МЕТОДИ У ВИВЧЕННІ УКРАЇНСЬКЇ МОВИ ЯК ІНОЗЕМНОї У ЗВО
}

\author{
Матвіснко Т. I. \\ кандидат філологічних наук, доцент \\ Київського національного університету театру, кіно і телебачення \\ імені І. К. Карпенка-Карого \\ м. Київ, Украӥна
}

Зважаючи на всі трансформації освітньої системи України, можна вести мову про вихід української вищої освіти на якісно новий рівень, що зумовлює зростання популярності українських вищих навчальних закладів на міжнародному ринку освітніх послуг, як результат, кількість іноземних студентів в українських закладах вищої освіти суттєво зростає. За рахунок того, що українська мова має статус державної та активно використовується у всіх сферах людської діяльності, починаючи із обов'язкового використання у всіх органах влади, закінчуючи теле-та радіо віщанням, перед іноземними громадянами постає проблема вивчення української мови як іноземної, а перед викладачами ВНЗ виникає проблема у сприйнятті української мови як іноземної, виборі таких методів та прийомів освітньої діяльності, які б дозволили вирішити поставлені перед ними завдання [1, c.143].

Методика викладання української мови як іноземної порівняно молода наука, саме тому вона викликає у педагогів та методистів непідробний інтерес до застосування інноваційних підходів у даній галузі. За рахунок того, що даний напрям освітньої діяльності лише розвивається, виникає потреба у визначені тих методів та прийомів, які дозволять досягти максимально якісного рівня підготовки іноземних студентів під час їхнього навчання у ВНЗ України.

Актуальності набувають питання не лише мовознавчих досліджень спрямованих на визначення загальних методів та прийомів, які $\epsilon$ актуальними при вивченні української мови як іноземної, а й якісної організації освітньої діяльності іншомовних громадян під час здобування ними вищої професійної освіти в українських ВНЗ загалом [4, c. 229-230].

Якісно організований освітній процес передбачає чітку постановку мети та завдань навчального курсу, навчальної програми, або процесу здобуття конкретної професії загалом, тому проблема якісної організації 
навчальної діяльності є загальноосвітньою. 3 урахуванням того аспекту, що для іноземних громадян окремо необхідно впроваджувати дисципліни, які дозволяють їм вивчати українську мову як іноземну, проблеми знання мови викладачами, їх культура спілкування, вміння застосовувати діловий та вільний стилі українського мовлення стають першочерговими. Викладач, який здійснює викладання української мови як іноземної, повинен не просто вільно нею володіти, він повинен прагнути до передачі ії глибинного сенсу, змістовного наповнення [5].

Викладаючи українську мову як іноземну, викладач повинен організувати роботу таким чином, щоб не просто познайомити студентів 3 мовою, яка $є$ для них чужою, а формувати та розвивати у них пізнавальний інтерес до вивчення мови, бажання вивчати іiі та вільно нею розмовляти. Ефективним в даному процесі є використання інноваційних та інтерактивних методів навчання[2, с. 152-153].

Серед інструментів ефективної педагогічної взаємодії під час вивчення української мови як іноземної є: полілог, діалог, міжсуб'єктні відносини, свобода вибору, ситуації успіху, позитивний підхід до оцінювання роботи, рефлексія і т.п. Серед інтерактивних форм роботи найбільш ефективними будуть: «Незакінчені речення», «Мозковий штурм», «Вилучи зайве», «Обмін думками», «Інтерв’ю», «Роз’єднай слова», «Дешифрувальник», «Гронування», «Алітерація імені» (особливо ефективно використовувати під час організації знайомства групи або під час вивчення теми «Зовнішність і характер людини»), «Заверши фразу», «Комплімент», «Прогноз погоди», «Асоціації», «Алфавіт»,»Хвилина розмови», «Зміна співрозмовника» (тренування діалогічного мовлення) та інші [3, с. 25].

Одним із найбільш ефективних методів навчання $\epsilon$ навчання iз використанням інформаційно-цифрових технологій (комп’ютерних i мультимедійних засобів, мережі Internet). Використання комп'ютера не лише надає доступ до невичерпних джерел інформації, а й дозволяє використовувати цифрові технології для розвитку пізнавального інтересу іноземних студентів у вивчення української мови. Використання інформаційно-цифрових технологій відкриває окремий ряд можливостей як для студента так і для викладача. Так, починаючи із звичайних презентацій, зроблених за допомогою програми Power Point, які можуть використовуватись викладачем під час пояснення матеріалу, так i студентом під час презентації результатів власної діяльності, закінчуючи застосуванням технологій дистанційного навчання, процес вивчення української мови стає значно цікавішим. 3 використанням IКТ доцільним $\epsilon$ застосування таких методів як: 
- метод сценарію, який передбачає планування діяльності, підготовку матеріалу із використанням IКТ, добір гіпотез відповідно до визначеної тематики та підготовку презентацій на завершальному етапі;

- метод симуляцій, який базується на принципах відтворення конкретної ситуації, яка вимагає обговорення та прийняття рішення, яке, в даній ситуації, $\epsilon$ найбільш правильним та ефективним;

- рольові ігри, що не лише дозволяють стимулювати процес розвитку та вдосконалення навичок усного мовлення, а й дозволяють формувати у іноземних студентів цілісну картину, яка відображає українські звичаї, традиції, менталітет під час ознайомлення їx iз українськими літературними творами та композиціями;

- самостійна робота студента із використанням IКT під час виконання окремих завдань або навчальних проектів спрямованих на розвиток їх мовленнєвої компетенції та вдосконалення навичок українського усного та писемного мовлення;

- контроль за результатами навчальної діяльності студентів [1;2;4].

На сьогоднішній день, зважаючи на те, що у всьому світі $\epsilon$ поширеною пандемія, спричинена вірусом COVID-19, а освітній процес у вищих навчальних закладах більшою мірою організовано дистанційно, саме використання IКТ стає не просто ефективним методом, а єдиним можливим за даних умов. Використання ІКТ під час дистанційного навчання, зокрема при вивченні української мови як іноземної, $\epsilon$ ефективним за умови використання наступних методів:

- метод конференцій, який передбачає використання відео зв'язку для формування та вдосконалення навичок усного мовлення, діалогічного спілкування та колективного ознайомлення із новим навчальним матеріалом;

- самостійного опрацювання презентаційного, фото, відеоматеріалу 3 метою визначення теоретичних основ усного або писемного мовлення;

- представлення результатів навчальної діяльності у формі фото та відео звітів, презентацій.

- проведення контролю знань у формі відкритих або закритих тестових завдань, виконання яких $є$ обмеженим в часі.

Враховуючи особливості використання ІКТ при вивченні української мови як іноземної, застосування інноваційних методів навчання вимагає розробку науково-методичних засад, що, насамперед передбачає:

- конкретизацію концептуальних засад вивчення української мови як іноземної;

- розробку нових та вдосконалення вже існуючих комунікативних методик вивчення української мови; 
- враховуючи рівень розвитку та використання інноваційних технологій в сучасній лінгводидактиці та лінгвометодології, розширення способів навчання та методів, які при цьому використовуються;

- розробка та вдосконалення науково-методичних засад, які $\epsilon$ актуальними при викладанні української мови в іншомовній аудиторії, за умови узагальнення національних лінгводидактичних традицій;

- вивчення та аналіз передового світового досвіду із впровадження інноваційних технологій викладання національних мов як іноземних $[1 ; 6]$.

Підводячи підсумок, можемо вести мову про те, що вивчення української мови як іноземної відбувається на основі базових методів навчання, але найбільш ефективними $є$ інноваційні лінгвістичні та лінгводидактичні методи, які спрямовані на формування та вдосконалення навичок усного та писемного мовлення у іноземних студентів. В умовах дистанційної освіти ефективним $\epsilon$ використання інформаційно-комунікаційних технологій, серед яких такі як конференції, самостійне опрацювання теоретичного матеріалу, презентація власних результатів діяльності у формі презентацій, фото звітів або пройдених в режимі online контрольних та тестових завдань.

\section{Література:}

1. Касьяненко Т.А. Особливості вивчення української мови як іноземної у вищих мистецьких навчальних закладах. Вопросы духовной культуры - Филологические Науки.2013. С. 143-146

2. Корженко В.Я., Опанасюк М.М. Інноваційні методи викладання української мови як іноземної у технічному університеті. Вісник Вінницького політехнічного інституту. 2011. № 1. С. 152-155

3. Мазурик Данута Критерії визначення рівня володіння українською мовою як іноземною. Вісник Львівського університету. 2009. Вип. 4. С. 27-34.

4. Мацько Л. Інноваційні технології викладання української мови як іноземної на підготовчому відділенні університету. Теорія $і$ практика викладання української мови як іноземної. 2011. №. 6. С. 229-238.

5. Соколова С. В. Методика формування граматичної компетенції 3 української мови як іноземної : навч.- методич. пос. / С. В. Соколова; М-во освіти i науки, молоді та спорту України, НПУ імені М. П. Драгоманова, Ін-т укр. філології. - К.: Вид-во НПУ імені М. П. Драгоманова. 2011. 122 с. 
6. Українська мова у світі. Збірник матеріалів II Міжнародної науково-практичної конференції. Львів: Національний університет «Львівська політехніка». 2012. 368 с.

DOI https://doi.org/10.30525/978-9934-26-039-1-9

\title{
СТРУКТУРНО-СЕМАНТИЧНА ХАРАКТЕРИСТИКА ТОПОНІМІЧНИХ НАЗВ УКРАЇНСЬКИХ ГРАМОТ ХV СТ. У СТАРОУКРАЇНСЬКІЙ МОВІ
}

\author{
Могильна Л. I. \\ магістрантка \\ Навчально-наукового інституту украӥнської філології \\ та сочіальних комунікацій \\ Черкаського національного університету імені Богдана Хмельницького \\ м. Черкаси, Украӥна
}

Уживання староукраїнської мови в актовій діловій мові XV ст. засвідчило, що українська мова була однією 3 найрозвиненіших мов світу, оскільки ділова документація велася цією мовою в державахзагарбниках, адже їхні мови не мали великої писемної традиції та й не було фахівців для ділового письма в канцеляріях, тому князі, воєводи литовські, молдавські, польські воєводи користувалися староукраїнською мовою у своїх канцеляріях, листуванні. [5].

Українські грамоти XV ст., які є об'єктом нашого дослідження, проаналізовано за двома ознаками: 1) територіальна ознака; 2) семантична наповнюваність досліджуваних документів, тобто зміст грамот. Центральний повіт воєводства, на території якого розташовувався адміністративний центр, інколи називали каштелянією, яку очолював каштелян, що був на цій території помічником воєводи [1]. М. С. Антошин виокремлює внутрішні та зовнішні грамоти. До внутрішніх належать, на думку мовознавця, жалувані, дарчі, продажні, підтвердні, пільгові, судні, роздільні, мінові, управлінські, заповітні; до зовнішніх - договірні, торгові, посольські й листи [2].

М. М. Пещак староукраїнські грамоти поділяє умовно на два типи: 1) документи, що відображають внутрішньодержавні юридичні стосунки (дарчі, вкладні, купчі, продажні, заставні, роздільні, підтвердні грамоти та свідчення); 2) документи, що відображають міждержавні відносини (присяжні, поручні, договірні грамоти, привілеї [3, с. 58-61]. 